\title{
A metaphylactic treatment with double dose oxytetracycline reduces the risk of bovine respiratory disease in feedlot calves
}

\author{
Fazzio, L.E.; Giuliodori, M.J.; Galván, W.R.; Streitenberger, N.; Landoni, M.F. \\ Facultad de Ciencias Veterinarias, Universidad Nacional de La Plata, calles 60 y 118, \\ La Plata (1900), Provincia Buenos Aires, Argentina. E-mail: fazzio@fcv.unlp.edu.ar
}

\begin{abstract}
Fazzio, L.E.; Giuliodori, M.J.; Galván, W.R.; Streitenberger, N.; Landoni, M.F.: $A$ metaphylactic treatment with double dose oxytetracycline reduces the risk of bovine respiratory disease in feedlot calves. Rev. vet. 26: 2, 89-92, 2015. The objective of this study was to evaluate the effect of a metaphylactic treatment with oxytetracycline (OTC) in the labeled and double doses on the risk for bovine respiratory disease (BRD) in feedlot calves. This study was conducted in a commercial feedlot where 2,754 calves belonging to high risk groups were enrolled. A randomized complete block design was used, with animals as experimental units and pens $(\mathrm{n}=10)$ as blocks. Three experimental groups were assessed: 1- untreated control (CTL), 2- OTC $20 \mathrm{mg} / \mathrm{kg} \mathrm{SC} \mathrm{(OTC20)} \mathrm{and} \mathrm{3-} \mathrm{OTC} 40 \mathrm{mg} / \mathrm{kg} \mathrm{SC}$ (OTC40). The risk for BRD was evaluated with a mixed logistic regression. Untreated CTL had 2.85 and 7.14 more chances of getting BRD than OTC20 and OTC40 groups, respectively $(p<0.001)$. In conclusion, metaphylactic treatment with OTC is useful to reduce the risk for BRD in feedlot cattle, being protective effect higher at double dose than at labeled one.
\end{abstract}

Key words: calf, bovine respiratory disease, oxytetracycline, metaphylactic treatment.

\begin{abstract}
Resumen
Fazzio, L.E.; Giuliodori, M.J.; Galván, W.R.; Streitenberger, N.; Landoni, M.F.: Un tratamiento metafiláctico con doble dosis de oxitetraciclina reduce el riesgo de enfermedad respiratoria bovina en terneros de engorde a corral. Rev. vet. 26: 2, 89-92, 2015. El objetivo del presente estudio fue evaluar el efecto del tratamiento metafiláctico con oxitetraciclina (OTC), a simple y doble dosis, en bovinos con alto riesgo de padecer enfermedad respiratoria bovina (ERB). El estudio se realizó en un establecimiento de engorde a corral donde se utilizaron 2.754 terneros que fueron considerados de alto riesgo de padecer ERB. Se utilizó un diseño en bloque completamente al azar donde se consideró al animal como la unidad experimental y el corral $(\mathrm{n}=10)$ como bloque. Se formaron tres grupos experimentales: 1- control (CTL) el cual permaneció sin tratamiento, 2- recibió OTC $20 \mathrm{mg} / \mathrm{kg} \mathrm{SC}$ (OTC20) y 3- recibió OTC $40 \mathrm{mg} / \mathrm{kg}$ SC (OTC40). El riesgo de ERB fue evaluado a través de una regresión logística. Los animales del grupo CTL tuvieron 2,85 y 7,14 veces más chances de enfermarse de ERB que los animales de los grupos OTC20 y OTC40 respectivamente $(\mathrm{p}<0,001)$. En conclusión, el tratamiento metafiláctico con OTC es útil para reducir el riesgo de padecer ERB en engorde a corral, siendo su efecto mayor cuando se aplica a la dosis de $40 \mathrm{mg} / \mathrm{kg}$.
\end{abstract}

Palabras clave: ternero, enfermedad respiratoria bovina, oxitetraciclina, tratamiento metafiláctico.

\section{INTRODUCTION}

Bovine respiratory disease (BRD) is the single most important health problem in feedlot cattle ${ }^{12,19}$. It is well known that BRD causes lower daily weight gains, poor feed efficiency and carcass quality, and death ${ }^{10,19,23}$. It has been reported that BRD is the re-

Recibido: 8 octubre 2014 / Aceptado: 12 noviembre 2014 sult of a complex interaction among infectious agents, stress, management and individual susceptibility ${ }^{16,21}$. Among infectious agents involved are viruses and bacteria such as Pasteurella multocida and Mannheimia haemolytica ${ }^{6,18}$. Many authors have reported that metaphylactic treatment with drugs such as ceftiofur, florfenicol, tilmicosin, tulathromycinand, and oxytetracycline (OTC) is a useful tool to reduce the number of BRD-affected animals within a population ${ }^{4,7,20}$. In this 
sense, OTC is a broad-spectrum antibiotic with a good tissue distribution that is available in long-acting preparations and therefore, it would be suitable for metaphylactic use ${ }^{2,5,20}$. The use of long acting OTC preparations subcutaneous (SC) in calves has advantages over IM administration route for eliminating damage to edible meat and it has been approved by FDA ${ }^{8,24}$.

In addition, OTC treatment effect could be enhanced if the drug is administered at a higher dose, $40 \mathrm{mg} / \mathrm{kg}{ }^{22}$. However, no study has compared the metaphylactic effect of a single administration of OTC at labeled $(20 \mathrm{mg} / \mathrm{kg})$ vs double dose $(40 \mathrm{mg} / \mathrm{kg})$ in feedlot calves. Therefore, the objective of this study was to evaluate the effect of a metaphylactic treatment with OTC in the labeled and double doses on the risk for BRD in feedlot calves. The working hypothesis was that a metaphylactic treatment with OTC reduces the risk for BRD in feedlot, and that the efficacy of the double dose is higher.

\section{MATERIAL AND METHODS}

This study was conducted in a commercial feedlot located in Marcos Paz, Buenos Aires Province, Argentina $\left(34^{\circ} 08^{\prime} \mathrm{S}, 58^{\circ} 08 \mathrm{~W}\right)$. Male and female calves $(\mathrm{n}=$ 2,754 ) from Hereford, A. Angus, Bradford and Brangus breeds with an entrance weight of $120 \pm 22 \mathrm{~kg}$ (mean \pm SD) were enrolled. Animals were kept for $72 \mathrm{~h}$ in admission pens with free access to high quality hay and clean water. Then, calves were identified (ear tags) and received a SC single dose of a polyvalent clostridium vaccine (Policlostrigen, Biogénesis-Bagó, Argentina) and a $\mathrm{SC}$ single dose of ivermectin (Ivergen Biogénesis-Bagó, Argentina). Diet was based on corn grain, sunflower meal, wheat bran and vitamin-mineral supplement. Fiber content of the initial ration was $25 \%$ and then decreased progressively up to $5 \%$ in the finishing ration.

The inclusion criteria considered as "high risk group for BRD" to those groups where at least $10 \%$ of the calves showed poor body condition score, eye and/or nasal discharge, and cough at the start of the study. Duration of the trip from auction market to feedlot, weather conditions and lack of health records were also taken into account. A randomized complete block design was used, with animals $(n=2,754)$ as experimental units and pens $(n=10)$ as blocks. In each pen three experimental groups were randomly formed: 1- untreated control (CTL, $n=893), 2$ Oxytetracyclin $20 \mathrm{mg} / \mathrm{kg}$ SC (OTC20, Maxibiotic 20\% Biogénesis-Bagó, Argentina, $\mathrm{n}=900$ ), and 3- Oxytetracyclin $40 \mathrm{mg} / \mathrm{kg} \mathrm{SC}$ (OTC40, Maxibiotic 20\% Biogénesis-Bagó, Argentina, $n=$ 961). All the studied animals were kept in their assigned pens, so that no animal was allowed either to enter or to change the pen once the experiment was in progress.

Animals in pens were observed twice daily by trained personnel in the diagnosis of BRD. Animals showing signs of BRD (depression, eye or nose discharge, anorexia, dyspnea, cough, rectal temperature $\geq 39.5^{\circ} \mathrm{C}$, orthopneic posture) received a rescue therapeutic treatment with tilmicosin SC 10 $\mathrm{mg} / \mathrm{kg}$ (Micotil, Elanco Animal Health) plus meloxicam $0.5 \mathrm{mg} / \mathrm{kg}$ (Metacam 20\% Boehringer Ingelheim). Dead animals were necropsied and collected tissues sampled for bacteriological analysis. All the cases of BRD, treatments, and related deaths were recorded. In one of the pens, 90 animals (30 per group) were randomly selected and their liveweights measured on days 0,21 , and 50 .

The risks for BRD and for death as a consequence of BRD were evaluated by using a mixed logistic regression with a binomial distribution and a logit link function. The logistic model included the fixed effect of treatment (CTL vs OTC20 vs OTC40) and the random effect of pens ${ }^{14,15}$. The interval of time to BRD occurrence was evaluated with a cox proportional hazard regression analysis with the fixed effect of treatment (CTL vs OTC20 vs OTC40) and also with a KaplanMeier survival analysis ${ }^{1}$. Average daily weight gains (ADG) were evaluated by using a linear mixed model that included the fixed effect of treatment (CTL vs OTC20 vs OTC40) and the random effect of the animal ${ }^{16}$. Statistical significance was set at $\mathrm{p}<0.05$ and a trend for significance at $\mathrm{p}<0.10$ and $>0.05$.

\section{RESULTS}

The incidence of BRD decreased from 7.95\% in the CTL group up to $3.33 \%$ in the OTC20 and up to $1.24 \%$ in the OTC40 group (Table 1). The metaphylactic treatment with OTC reduced the risk for BRD (Table 1). Untreated animals (CTL) had $2.85(1 / 0.35)$ more chances of getting BRD than the OTC20, and 7.14 (1/0.14) more chances of having BRD than the OTC40 animals (Table 1).

In addition, metaphylactic treatment with OTC reduced the hazard ratio for $\mathrm{BRD}(\mathrm{HR}=0.39,95 \%$ $\mathrm{CI}=0.30-0.51, \mathrm{p}<0.001$, Figure 1), and extended 7 days the interval of time from arrival to the diagnosis of BRD in all the calves becoming sick (Figure 2). That is, CTL group had a median $(95 \% \mathrm{CI})$ of 9 (8-13) days to BRD, while OTC20 had 16 days (14-24) and OTC40 had 16.5 $(15-22)$ days to disease $(\log$ rank test: $\mathrm{p}=0.005, \mathrm{df}=2)$.

Table 1. Effect of metaphylactic treatment with oxytetracycline on the risk for bovine respiratory disease in feedlot calves $(n=2,754)$

\begin{tabular}{lccccc}
\hline \multirow{2}{*}{ treatment } & \multicolumn{2}{c}{ incidence } & \multicolumn{3}{c}{ risk of bovine respiratory disease } \\
\cline { 2 - 6 } & $\%$ & $\mathrm{n}$ & OR & IC 95\% & $\mathrm{p}$ \\
\hline CTL & 7.95 & $71 / 893$ & referent & - & $<0.001$ \\
OTC20 & 3.33 & $30 / 900$ & 0.352 & $0.181-0.683$ & \\
OTC40 & 1.24 & $12 / 961$ & 0.141 & $0.077-0.259$ & \\
\hline
\end{tabular}

$\mathrm{OR}=$ odds ratio; $\mathrm{IC} 95 \%=95 \%$ confidence interval; $\mathrm{CTL}=$ control group left untreated; OTC20 = group treated with a single dose of oxytetracycline $(20 \mathrm{mg} / \mathrm{kg})$; OTC40 = group treated with a single dose of oxytetracycline $(40 \mathrm{mg} / \mathrm{kg})$. 
Table 2. Mixed model effects of the metaphylactic treatment with oxytetracycline on average daily weight gain in feedlot calves $(\mathrm{n}=90)$

\begin{tabular}{lccccc}
\hline \multirow{2}{*}{ ADG } & \multicolumn{3}{c}{ LSM $^{\mathrm{d}}$} & \multirow{2}{*}{ SE $^{\mathrm{e}}$} & $\mathrm{p}$ \\
\cline { 2 - 4 } & $\mathrm{CTL}^{\mathrm{a}}$ & $\mathrm{OTC}^{\mathrm{b}}$ & OTC40 $^{\mathrm{c}}$ & & \\
\hline ADGt $^{\mathrm{f}}$ & $939.4^{\mathrm{X}}$ & $1015.8^{\mathrm{X}, \mathrm{Y}}$ & $1028.4^{\mathrm{Y}}$ & 28.7 & 0.062 \\
ADG1 $^{\mathrm{g}}$ & $547.9^{\mathrm{X}}$ & $817.4^{\mathrm{Y}}$ & $905.3^{\mathrm{Y}}$ & 60.1 & $<0.001$ \\
ADG2 $^{\mathrm{h}}$ & $1217.6^{\mathrm{X}}$ & $1158.6^{\mathrm{X}}$ & $1116.5^{\mathrm{X}}$ & 38.4 & 0.180 \\
\hline
\end{tabular}

${ }^{\mathrm{a}} \mathrm{CTL}=$ control group $(\mathrm{n}=30)$ left untreated; ${ }^{\mathrm{O} O T C 20}=$ group treated $(\mathrm{n}=30)$ with a single dose of Oxytetracycline $(20 \mathrm{mg} / \mathrm{kg})$; ${ }^{\mathrm{c}} \mathrm{OTC} 40=$ group treated $(\mathrm{n}=30)$ with a single dose of Oxytetracycline (40 mg/kg); ${ }^{\mathrm{L}} \mathrm{LSM}=$ least squared means; ${ }^{\text {eSE }}=$ standard errors (highest value reported); ${ }^{\mathrm{f}} \mathrm{ADGt}=$ average daily gain (in grams) during all the study period (50 days); ${ }^{\mathrm{g}} \mathrm{ADG} 1$ = average daily gain (in grams) from 0 through 21 days of study (period 1); ${ }^{\text {h}} \mathrm{ADG} 2=$ average daily gain (in grams) from 21 through 50 days of study (period 2); ${ }^{\mathrm{X} Y \mathrm{Y}}$ Different capital letters within rows means $\mathrm{p}<0.05$.

Mortality rates were $0.22,0.11$ and $0.10 \%$ for CTL, OTC20 and OTC40, respectively. Four dead calves were observed ( 2 in CTL, 1 in OTC20, and 1 in OTC40). It was not possible to estimate the effects of OTC on the risk for death because there were very few dead animals. Bronchopneumonia was diagnosed in 3 animals ( 2 in CTL, and 1 in OTC20), while pleuroneumonia was diagnosed on the dead calf belonging to the OTC40 group.

Consolidated and dark red lesions showed cranioventral distribution in both lungs. Bacteriological studies showed the presence of Pasteurella multocida $(\mathrm{n}=1)$ and Mannheimia haemolytica $(\mathrm{n}=1)$ in CTL, Pasteurella multocida and Mannheimia haemolytica $(\mathrm{n}=1)$ in OTC20, and Mannheimia haemolytica $(\mathrm{n}=1)$ in OTC40.

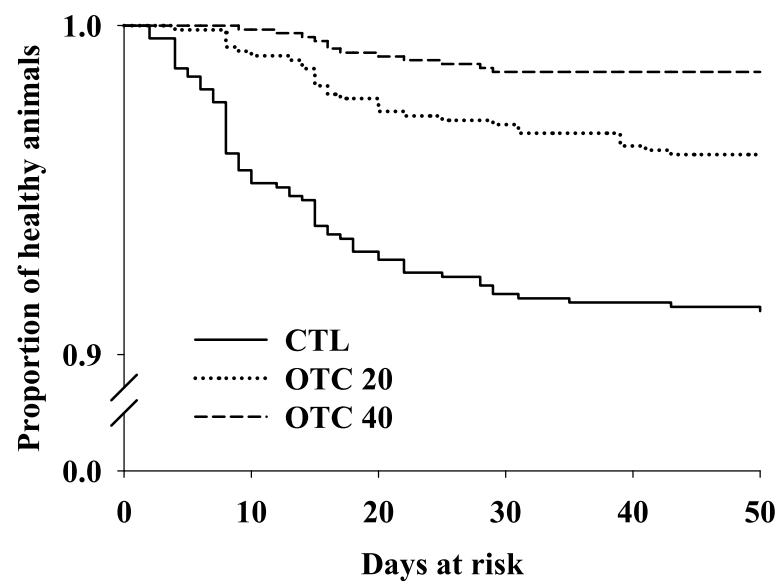

Figure 1. Effect of metaphylactic treatment with oxytetracycline on the interval of time from arrival to the diagnosis of bovine respiratory disease in feedlot calves ( $\mathrm{n}=2,754$, Control [CTL], Oxytetracycline $20 \mathrm{mg} / \mathrm{kg}$ [OTC20], and Oxytetracycline $40 \mathrm{mg} / \mathrm{kg}$ [OTC40]).
Susceptibility tests performed on isolated strains showed high sensitivity to OTC, tilmicosin, florfenicol, phosphomycin, and streptomycin.

Metaphylactic treatment with OTC showed an effect on average daily gain (ADG) during the entire study time, although it did not reach statistical significance $(p=0.062$, Table 2); CTL animals gained $76.4 \mathrm{~g} / \mathrm{d}$ less than OTC20 $(\mathrm{p}=0.059)$, and $89.0 \mathrm{~g} / \mathrm{d}$ less than OTC40 animals $(\mathrm{p}=0.030)$. The ADG during the first 21 days of study was affected by OTC ( $\mathrm{p}<0.001$, Table 2$)$; CTL gained $269.5 \mathrm{~g} / \mathrm{d}$ less than OTC20 $(\mathrm{p}=0.001)$ and 357.4 $\mathrm{g} / \mathrm{d}$ less than OTC40 ( $\mathrm{p}=0.001)$. Finally, ADG during the last 29 days of study was not affected by OTC administration $(\mathrm{p}=0.180$, Table 2$)$.

\section{DISCUSSION}

The hypothesis of this study was that a metaphylactic treatment with OTC reduces the risk for BRD in feedlot cattle. In support of this hypothesis it was found that the incidence of BRD and the risk of BRD decreased after OTC treatment at both, labeled and double therapeutic doses. This result is expected on the basis that OTC is classified as a type III antimicrobial with time-dependent killing and moderate persistent effects. Therefore, ideal dosing regimen for these antibiotics maximizes the amount of drug received, being the area under the serum concentration curve/ minimum inhibitory concentration ratio the parameter that best correlates with efficacy ${ }^{13,17}$.

Another interesting finding was that the hazard ratio for BRD was also reduced by OTC treatment and therefore, the median interval of time from arrival to BRD diagnosis was extended (approximately 7 days) by OTC treatment. This could be explained for the long lasting effect of OTC; treated animals are under the

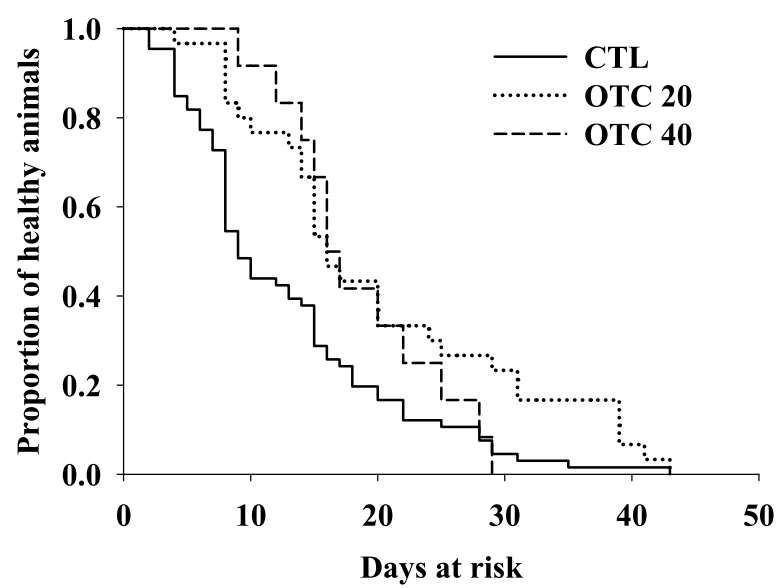

Figure 2. Effect of metaphylactic treatment with Oxytetracycline on the interval of time from arrival to the diagnosis of bovine respiratory disease in feedlot calves that developed the disease during the study $(n=71$ for Control [CTL], $\mathrm{n}=30$ for Oxytetracycline $20 \mathrm{mg} /$ $\mathrm{kg}$ [OTC20], and $\mathrm{n}=12$ for Oxytetracycline $40 \mathrm{mg} / \mathrm{kg}$ [OTC40]). 
protective effect of OTC shortly after arriving when the risk for BRD is the highest ${ }^{21}$. In fact, it has been reported that administration of a single dose of 20 and 40 $\mathrm{mg} / \mathrm{kg}$ of OTC to calves produced lung concentrations of $2 \mu \mathrm{g} / \mathrm{ml}$ for 48 and $72 \mathrm{~h}$, respectively ${ }^{22}$.

Regarding ADG, CTL animals gained less weight during the study than the two OTC groups. This finding is expected since a higher proportion of animals were affected by BRD in the CTL group than in the OTC groups. One reason could be that sick calves have a lower dry matter intake what would decrease $\mathrm{ADG}^{9,23}$. Another reason could be that sick animals shift energetic fuels from productive tissues to defense tissues in an attempt to save "fuel" to match the higher demands of the immune system fighting against lung infection ${ }^{3,11}$. These facts could explain why BRD-affected animals gain less weight than healthy pen-mates.

In conclusion, metaphylactic treatment with OTC reduces the risk for BRD in feedlot cattle, and that the protective effect is higher at double dose than at labeled one. In addition, metaphylactic treatment with OTC improves weight gain during the first weeks after feedlot entrance.

Acknowledgements. The authors thank feedlot's owner and personnel for their support.

\section{REFERENCES}

1. Allison PD. 1995. Survival Analysis Using SAS: a practical guide. SAS Institute Inc, Cary, NC, p. 29-184.

2. Aronson AL. 1980. Pharmacotherapeutics of the newer tetracyclines. J Am Vet Med Assoc 176: 1061-1068.

3. Borghetti P, Saleri R, Mocchegiani E, Corradi A, Martelli P. 2009. Infection, immunity and the neuroendocrine response. Vet Immunol Immunopathol 130: 141-162.

4. Catry B, Duchateul L, Van de Ven J, Laevens H, Opsomer G, Haesebrouck F, De Kruif A. 2008. Efficacy of metaphylactic florfenicol therapy during natural outbreaks of bovine respiratory disease. $J$ Vet Pharmocol Therap 31: 479-487.

5. Cusack PM. 2004. Effect of mass medication with antibiotics at feedlot entry on the health and growth rate of cattle destined for the Australian domestic market. Aust Vet J 82: 154-156.

6. Dabo SM, Taylor JD, Confer AW. 2007. Pasteurella multocida and bovine respiratory disease. Anim Health Res Rev 8: 129-150.

7. Daniels TK, Bowman JG, Sowell BF, Branine ME, Hubbert ME. 2000. Effects of metaphylactic antibiotics on behavior of feedlot calves. Prof Anim Scientist 16: 247-253.

8. FDA. 2002. $A N A D A$, p. 200-306. On line: http://www.fda. gov/downloads/Animal Veterinary/Products/ApprovedAnimalDrugProducts/FOIADrugSummaries/ucm061 758.pdf

9. Jim GK, Booker CW, Ribble CS, Guichon PT, Thorlakson BE. 1993. A field investigation of the economic impact of respiratory disease in feedlot calves. Can Vet $J$ 34: 668-673.
10. Keita A, Pommier P, Pagot E, Couper A, Cromie L. 2007. A combination oxytetracycline/flunixin treatment of respiratory infections in cattle. Rev Med Vet 158: 86-91.

11. Kelley KW, Weigent DA, Kooijmann R. 2007. Protein hormones and immunity. Brain Behav Immunol 21: 384392.

12. Kelly AP, Janzen ED. 1986. A review of morbidity and mortality rates and disease occurrence in North American feedlot cattle. Can Vet J 27: 496-500.

13. Li RC, Zhu ZY. 2002. The integration of four major determinants of antibiotic action: bactericidal activity, postantibiotic effect, susceptibility, and pharmacokinetics. $J$ Chemother 14: 579-583.

14. Montgomery DC. 2009. Experiments with blocking factors. In: Design and Analysis of Experiments (Ibid.Ed.), $7^{\text {th }}$ ed, Wiley \& Sons, West Sussex, UK, p. 121-138.

15. Myers RH, Montgomery DC, Vining GG, Robinson TJ. 2010. Random effects in Generalized Linear Models. In: Generalized Linear Models with Applications in Engineering and the Sciences (Ibid.Ed.), $2^{\text {nd }}$ ed, Wiley \& Sons, Hoboke, NJ, USA, p. 319-407.

16. Nickell JS, White BJ. 2010. Metaphylactic antimicrobial therapy for bovine respiratory disease in stocker and feedlot cattle. Vet Clin North Am, Food Anim Pract 26: 285-301.

17. Nicolau DP. 2003. Optimizing outcomes with antimicrobial therapy through pharmacodynamic profiling. J Infect Chemother 9: 292-296.

18. Rice JA, Carrasco L, Hodgins DC, Shewen PE. 2007. Mannheimia haemolytica and bovine respiratory disease. Anim Health Res Rev 2: 117-128.

19. Schunicht OC, Booker CW, Guichon PT, Jim GK, Wildman BK, Hill BW, Ward TI, Bauck SW. 2002. An evaluation of the relative efficacy of a new formulation of oxytetracycline for the treatment of undifferentiated fever in feedlot calves in western Canada. Can Vet J 43: 940-945.

20. Schunicht OC, Booker CW, Guichon PT, Jim GK, Wildman BK, Pittman TJ, Perrett T. 2007. An evaluation of the relative efficacy of tulathromycin for the treatment of undifferentiated fever in feedlot calves in Nebraska. Can Vet J 48: 600-606.

21. Taylor JD, Fulton RW, Lehenbauer TW, Step DL, Confer AW. 2010. The epidemiology of bovine respiratory disease: What is the evidence for predisposing factors? Can Vet J 51: 1095-1102.

22. Terhune TN, Upson DW. 1989. Oxytetracycline pharmacokinetics, tissue depletion, and toxicity after administration of a long acting preparation at double the label dosage. J Am Vet Med Assoc 194: 911-917.

23. Thompson PN, Stone A, Schultheiss WA. 2006. Use of treatment records and lung lesion scoring to estimate the effect of respiratory disease on growth during early and late finishing periods in South African feedlot cattle. $J$ Anim Sci 84: 488-498.

24. Van Rij H, Huyghe B. 1999. The possibility of subcutaneous administration of Eng emycin in calves. VSD Newsletter. http://www.belvet.kiev.ua/templates/blt/files/cat tle_reproduction/The_possibility_of_subcutaneous_administrarion_of_Engemycin_in_calves.pdf 